NGTT Deel 54, Nommers 3 \& 4, September en Desember 2013

Modise, Leepo ${ }^{1}$

University of South Africa

\title{
The rocky road travelled by the Dutch Reformed Church in Africa towards church unity: from Tshilidzini to Pretoria, 1971 to $1991^{2}$
}

\begin{abstract}
This review of the rocky road travelled by the Dutch Reformed Church in Africa (DRCA) towards church unity consists of five parts. First, the historical background to the DRCA is briefly traced. Second, the author investigates the various decisions of the general synod of the DRCA regarding church unification from Tshilidzini in 1971 to Pretoria in 1991. Third, decisions of the general synod of the then DRCA on the fourth confession are considered. Fourth, the decision of the general synod regarding the Belhar Confession prior to 14 April 1994 and the unity talks among the then Dutch Reformed Church (DRC) members and their impact on unity are discussed. Fifth, the final decisions of the then DRCA regarding church unification with the Dutch Reformed Mission Church (DRMC) as the result of the delay on the part of the DRC are investigated.
\end{abstract}

\section{INTRODUCTION}

\section{The background}

As we trace the rocky road travelled by the Dutch Reformed Church in Africa (DRCA) towards unity, it is appropriate that we begin with a consideration of racial segregation in the Dutch Reformed Church (DRC) and why the need to unite the DRC family arose. Saayman (2007) reports that, the synod of 1834 dealt with two issues of direct importance to interracial worship, especially at Holy Communion. The synod pronounced unequivocally that nobody should be excluded from worship on the ground of race alone. It further stated that 'heathen' (non-white) members, baptised and catechised by ordained missionaries, would be considered full members of the local DRC. It is recorded that the real reason for this was that some congregations were increasingly unwilling to allow the administration of Holy Communion in an inter-racial setting, and so the question was submitted in order to get a clear injunction from synod whether or not such racial exclusivity was unacceptable (Dreyer, 1936; Saayman, 2007). Tingle (1992:12) indicates that division along racial lines in the DRC dates back to 1857 , when it was decided that, although not desirable or scriptural, owing to the weakness of some (whites) it was permissible to hold separate services for white and black people. Furthermore, some smaller white members of the DRC family became established on the basis of doctrinal differences.

The DRC simply continued to ignore the theological injunction and continued with racial

1 Dr Leepo Modise, Senior Lecturer in Systematic Theology in the Department of Philosophy, Practical and Systematic Theology, University of South Africa, Pretoria, South Africa.

2 This article was presented as a paper at the conference entitled Reformed Churches in South Africa and the Struggle for Justice Gender: Remembering 1960-1990, held at Stellenbosch University. 
NGTT: Oopbron - http://ngtt.journals.ac.za

segregation in ministry and mission in many congregations. From 1857, therefore, the DRC was a church divided along racial lines. A brief historical background of the DRCA in order to investigate historical events that contributed to make the road to church unity a rocky one should prove instructive. The decisions of a number of general synods regarding church unity will be investigated and evaluated. Moreover, debate about the formulation and adoption of the fourth confession of faith of the African church will be highlighted. In this article we will journey together to remember how the DRCA struggled to find a possible way to church unity and her efforts to confess anew that Jesus is Lord within one united body of Christ. The major obstacles to church unity, and the drafting and adoption of the fourth confession of faith will be highlighted. These obstacles include paternalistic cooperation between the DRC and DRCA; the federal council of the DRC family; white missionaries who occupied leadership positions in the DRCA; socio-economic factors; the discussion forum regarding church unity; and the perception of black ministers of their own inferiority.

\section{Aims of the study}

This article has five aims. The first is to briefly trace the historical background of the Uniting Reformed Church in Southern Africa (URCSA) as it developed from the DRC into the DRCA and Dutch Reformed Mission Church in South Africa (DRMC). The second aim is to investigate and evaluate decisions of the general synod of the then DRCA regarding church unity from Tshilidzini in Venda in 1971 to Hatfield in Pretoria in 1991. The third aim is to illustrate the attempts of the DRCA to decide on the formulation and adoption of the fourth confession of faith for the African church. The fourth is to consider decisions of the general synod about the Belhar Confession prior to 14 April 1994 and the unity talks among then DRCA members and their impact on unity.

\section{Historical BACKGROUND TO THE DRCA}

In 1652 the Dutch established a settlement in the Cape, and introduced reformed theology. Up until 1857 people of mixed decent as well as people of African heritage were accepted as fully fledged members of the DRC in South Africa. On 29 April 1829 the DRC synod dealt with an enquiry by the Somerset West congregation regarding separate facilities and services for congregants of mixed decent. At the infamous synod of the DRC in South Africa in 1857, approval was given for separate services for 'coloured' members of the church. This decision led to the division of Christians on the basis of colour at the table of the Lord as a matter of practice and policy, and was phrased as follows according to Thomas (2002:63):

The Synod considers it desirable and according to the Holy Scripture that our heathen members (non-whites) be accepted and initiated into our congregations wherever it is possible; but where this measure, as a result of the weakness of some, would stand in the way of promoting the work of Christ among the heathen people, then congregations set up among the heathen, or still to be set up, should enjoy their Christian privileges in a separate building or institution.

Thomas (2002:63) explains that in South Africa the DRMC had been established for coloured people by 1881 ; its purpose was not the same as that of the mission societies involved in church planting, but was rather to entrench racial segregation. The DRC saw the Mission Church not so much as a church moving towards autonomy, but rather as a coloured department of the mother church. The establishment of the DRCA was the outcome of mission work among the 
NGTT Deel 54, Nommers $3 \& 4$, September en Desember 2013

African population undertaken by the various synods of the DRC. At first, African converts were simply added to the DRMC. In time, separate churches and synods for African converts were established. The first to be created was the synod of the Orange Free State in 1910. Similar synods were created in the Transvaal in 1932, the Cape Province in 1951 and Natal in 1952. The separation between these synods came to an end in 1963, when the DRCA was formed. Eventually, in 1968, the Reformed Church in Africa (for Indians) came into being (Thomas, 2002:194; Meiring, 2004:120).

The DRCA, based on racial segregationist principles, has the same structure, doctrine, traditions, and customs as the mother church, which retains extensive control over it by supplying $80 \%$ of its budget. Its clergy may not serve white congregations and intercommunion between the two churches, even as a symbol of ecumenical unity, is prohibited. White ministers were trained specifically to serve the black congregations, and these ministers were to be watchdogs of the DRC in its mission churches, and decision-makers on behalf of the mission church.

From its inception the DRCA enjoyed no independence or autonomy as a church. It was stated in article 4 of the church order of 1932 of the DRCA, which was handed over to the black church, that white ministers must be members of the moderature of the synod of the black church, and that the DRC must have representatives at all levels of the black church, in other words, at synod, presbytery and church council level. This arrangement was very disturbing to many theologians and ministers of the Word within the DRCA and DRMC. The disunity in the DRC family was questioned, and the need to become what the church originally was, one church, was expressed. Believers from the black church wanted to be accepted as believers in Jesus Christ, and not constantly to be classified as black or coloured or Asian Christians. The DRCA therefore called for church unity in its different synods.

\section{ChURCH UNITY TALKS IN DIFFERENT SYNODS OF THE DRCA}

The DRCA, in its synods, viewed church unity as a gift, obligation and scriptural imperative. For the DRCA, the church is the body of Jesus Christ on earth - not many bodies, but one united body; this truth is vividly described in Paul's first letter to the Corinthians 1:12-31, where he compares the church to the human body, explaining that this body is a single, integrated, living organism whose every part supports, strengthens and intimately cooperates with every other part. There is no division or conflict in such a body; there is always the spontaneous mutual support which different organs give to one another. It is true that the limbs fulfil different offices and responsibilities, but all are servants of one another and cooperate closely in order to promote proper and successful functioning.

The DRCA felt the unity emphasised by Paul in this passage to be always central and crucial; although diversity is a reality which the church acknowledges and respects, it is always secondary. The DRCA in its synods was influenced by this passage and others dealing with church unity. They engaged in debates about the road to church unity. In the first place, the DRCA needed a compass to give it direction. It needed a confession of faith to express its stance amidst racial segregation, injustice and division in the church. There are therefore indications that the DRCA tabled the issue of the fourth confession of faith in the synods of Tshilidzini, Umgababa, Barkly West, Umtata, Cape Town and Pretoria.

\section{The general synod of Tshilidzini in 1971}

Discussions about race relations within the ecumenical movement were held as early as 
NGTT: Oopbron - http://ngtt.journals.ac.za

1946. From 1958 on, the agenda of the Reformed Ecumenical Synod (RES) declared there was no scriptural evidence either for or against mixed-race marriages. In 1968, the RES took the additional step of saying that Church and state may not prohibit mixed-race marriages. In 1968, the RES declared that the unity of the body of Christ should come to expression in common worship, including the administration and taking of Holy Communion, among Christians regardless of race. The RES also held a series of consultations with South Africans. The RES declaration and consultation in South Africa sparked a debate within the DRCA, the end result of which was the drafting of an African confession of faith encapsulating the standpoint of the African church. The matter was referred to the Federal Council of Dutch Reformed Churches for advice and reported to the general synod (Luke \& Van Houten, 1997).

Based on decision 11.2, the general synod of Tshilidzini stated the synod's acceptance of the recommendation of the federal council of the DRC that there should be no changes in creeds without consultation with the other member churches. This decision indicates that a proposal was tabled before the synod to discuss the possibility of an additional confession of faith. The federal council of the DRC was an obstacle to progress in that regard (NGKA Akta, 1971). Thomas (2002:63) reminds us that the federal council was established by the DRC in the 1940s, with no single, multiracial body to express the unity of the church. While the motives for establishing 'daughter churches' were initially based on racial considerations, they were later justified in terms of the three formulas which were, of course, also applied to the black churches founded by the DRC outside South Africa. The emphasis was on the salvation of individuals rather than on the salvation of whole peoples. In the light of the intention behind the establishment of the federal council, it was clear that it would not support any movement towards the establishment of a multiracial body to express church unity.

The influence of the leadership of the synod at that time should not be underestimated. The synod was led and advised by members of the DRC as per the church order of 1932. The influential positions of moderator and actuary were occupied by white missionaries, who were white South Africans who supported the order of the day. Thomas (2002:195) explains that white ministers in the DRCA had an influential voice:

There were also strong pragmatic factors which might have made it sympathetic to apartheid. Although legally autonomous, it was still extremely dependent on the NGK for financial subsidies, while the white missionaries of the 'mother church' working in the NGKA not only exercised a powerful influence within it, but remained members of, and responsible to, the white church rather than to the NGKA itself.

These missionaries remained loyal to the DRC and its apartheid policy. In consequence, the DRCA delayed implementing the decision of the synod on church unity.

It was the Afrikaans churches which in principle accepted that their white and black members should be segregated. Thomas (2002) states:

However, in terms of wealth and power it easily matched the resources of even the largest churches of the Ecumenical Bloc, particularly because after 1948 the members of successive apartheid-supporting Nationalist governments, practically without exception, were members of these churches. The close collusion between church and state was reinforced by the fact that the leading members of both the Nationalist government and the Dutch Reformed Churches belonged to the secret society known as the Afrikaner Broederbond, or the 'Band of Afrikaner Brothers'. That body was widely and popularly 
NGTT Deel 54, Nommers 3 \& 4, September en Desember 2013

believed to be the eminence grise guiding the policies and particularly the apartheid policies of the Nationalist government.

It was mainly as a result of the influence of the Afrikaans churches that the policy of apartheid or segregation between white and blacks in schools came to be accepted. Nevertheless, the very same white ministers in the DRCA subsequently supported a single, non-racial, united church in South Africa (Saayman, 2007).

\section{The general synod of Worcester of 1975}

Traditionally, the DRCA was led by white missionaries as per the church order of 1932 . The Worcester synod witnessed a turning point in terms of the leadership of the church. In this historical synod the first black moderator (the Rev ETS Buti) and first black scribe (SPE Buti) were elected, granting hope for sound debate on church unity arising from a change of leadership. This synod took a decision about church unity (NGKA Akta, 1975). Decision 1.2.6. can be summed up as follows: the general synod wished to unite with the Indian Reformed Church, Dutch Reformed Mission Church and Dutch Reformed Church in order to form one church, and instructed the synodical commission to meet with these churches to discuss the possibilities of church unity.

The role played by the white missionaries in the DRCA and the operational structure of the DRCA should not be overlooked. The powerful influence of the missionaries and congregational subsidies from the DRC affected the implementation of the decision. This decision became a threat to the DRC, because it viewed racial segregation as a means of protection from the other nations:

Racial separation was only widely accepted in the church in the early twentieth century, as many Afrikaners came to believe that their own survival as a community was threatened, and as the belief in racial separation was gaining acceptance among white South Africans in general. Social and spiritual survival became intertwined in church philosophy, influenced in part by the early twentieth-century persecution of the Afrikaners by the British (see British Imperialism and the Afrikaners, ch. 1). Church leaders refused to condemn Afrikaner rebellions against the British, and their followers gained strength by attributing divine origins to their struggle for survival. Reasons for church division were and are still deeply rooted in the South African social, political, cultural, personal and economic situation. One can therefore deduce that it was impossible for members of the DRC who were serving as ministers in the DRCA to support the decision of the general synod. The church is divided along the lines of class, economic disparity and material interests, and the poverty of the vast majority of black Christians compared with the relative affluence of their white counterparts is likely to be the most serious stumbling block to the expression of unity.

This decision had subsidy implications and was very difficult to implement: most of the black DRCA ministers would not insist on this decision because it might have resulted in a reduction in the subsidy from the white DRC, which supported a racially separated church and society. The new black leadership led the synod in taking the initiative towards achieving church unity, but the initiative did not progress as expected. The conservatives within the leadership and white advisors from the DRC diverted the process towards consultations and discussion forums. 
NGTT: Oopbron - http://ngtt.journals.ac.za

\section{The general synod of Umgababa of 1979}

During this synod the formulation of the fourth confession of faith was tabled and discussed intensively. According to the Acta of the synod of Umgababa of 1979, the synod tabled the point on the fourth confession of faith for all churches that were working together with the DRCA (decision 14.4 of the Umgababa synod). The debate on the formulation of the confession of faith was a point of departure for discussion on church unity in the context of the DRC family. With regard to decision 14.4.1.3, the synod decided that some issues remained unresolved within the DRCA, and the general synod did not take a decision on those issues. The synod instructed its commission on Bible study and confessions to formulate the draft of the fourth confession of faith as a statement of faith of the African church. This synod implemented the decision of the synod of Ottawa of 1978 on racism (and thus apartheid), where the reformed churches called for a status confessionis ${ }^{3}$ on the situation in South Africa. A status confessionis requires Christians to confess anew during times of heresy and false proclamation of the gospel. At such times the church needs to create a symbol as part of the confession of the church, where the church declares itself in the present so that the false teachings may be known and corrected. This synod therefore debated the possibility of formulating the fourth confession of faith as a means of achieving reconciliation, justice and unity (NGKA Akta 1979).

Furthermore, the synod decided on church unity for all members of the DRC family (NGKA Akta 1979). The synod instructed its General Synod Commission (GSC) to open negotiation for such unity with other members of the family; however, the GSC was required to take into account decision 1.2.6 of Worcester 1975 and was to report to the next general synod meeting. The tone of decision 14.4.1.3 reflected the character of the leadership in that synod: one of the black conservative members from the Umgababa leadership (the Rev MJ Lebone) was at that time the moderator; the actuary (the Rev NW Basson) was also a conservative member, with the scribe (Dr SPE Buti) being a radical member and the assessor (EM Mataboge) a moderate. Along the road to church unity leadership has made a significant contribution to either fast tracking or delaying the process. This synod used referral as a technique to delay the process; the next synod was to give feedback on the development of church unity (NGKA Akta 1979).

\section{The general synod of Barkly West of 1983}

The synod of Umgababa of 1979 had instructed the GSC to enter into negotiation with other members of the DRC family about church unity, and the report of the GSC on church unity was to be considered by the synod of Barkly West of 1983. This section will focus on the decisions of this synod regarding church unity.

The synod of Barkly West took a firm stand on church unity in decision 1.2.1. The decision was taken that church unity is an obligation that the church is required to meet, and that the church is to proclaim this unity wherever it proclaims the gospel. In the very same synod thorough preparations were made for church unity in terms of theological training for ministers. An interesting element of these preparations was the change in the DRCA theological training

\footnotetext{
3 Literally, status confessionis means a situation of confessing - a situation in which the confession of Jesus Christ is at stake. As stated in the Ottawa resolution of the World Alliance of Reformed Churches with regard to white Reformed Afrikaner Churches in South Africa, declaring that a situation constitutes a status confessionis means "that we regard this as an issue on which it is not possible to differ without seriously jeopardizing the integrity of our common confession."
} 
NGTT Deel 54, Nommers 3 \& 4, September en Desember 2013

curriculum to match that of the DRC, through the addition of the Bachelor of Arts (with Greek 1 and 2 and Hebrew 1 and 2) and Bachelor of Divinity (master's equivalent). The aim of the change in curriculum was to equip future black ministers who would be participating in the ministry of the united church. This decision was then referred to the order commission for further research on the possibility of church unity and negotiation with other DRC family members on the matter. The order commission was then required to report to the GSC. The moderature of the DRCA endeavoured to fulfil this mandate, and as a result, discussions were held with DRC family members (NGKA Akta 1983).

After the synod of Berkley-West there were discussions amongst the moderatures, executive committees and representatives of DRC family members. The composition of the discussion group members was as follows:

- $\quad$ DRC members: the Revv JE Potgieter, GSJ Möller and DJ Viljoen, and Doctors DCG Fourie and P Rossouw

- $\quad$ DRCM members: the Rev Mentor and Dr AJC Erwee

- DRCA members: the Revv MJ Lebone, EM Mataboge, NW Basson and Dr MS Pitikoe

- $\quad$ RCA members: No representative (NGKA Akta, 1987).

Of the ministers, $54 \%$ were white, $18 \%$ were coloured and $28 \%$ were black. One can deduce that on the basis of numbers, the white ministers would have dominated the group in terms of votes and the opportunity to speak. Thomas (2002:195) argues that although the DRCA was legally autonomous, it remained heavily dependent on the DRC for financial subsidies, while the white missionaries of the mother church working in the DRCA not only exercised a powerful influence within it, but remained members of, and responsible and accountable to the DRC rather than to the DRCA itself. Naturally the racism and division in the church benefited the white community. The financial culture of the time also determined the words and actions of black ministers in the DRCA, with the three conservative black ministers being affluent compared with those who were vocal on church unity.

According to the agenda of the general synod of the DRCA of 1987, the discussion group did not deal with the status confessionis or church unity, the purpose of the meeting being to placate the black church. The agenda for the March 1985 meeting between the executives of the DRC and the DRCA is revealing: the migration of labourers (people moving from the Bantustans to white cities), DRC subsidies to the DRCA ministers, and government social grants to black people. This meeting took place at the height of the apartheid struggle, when many black people lost their lives, but this was not raised as a topic. The DRC told the executive committee of the DRCA that the church's role in the country was joint prayer for all the people, but no engagement in politics (NGKA Akta 1987). During the discussion the point was expressed that if things are right in the church, they will automatically be right in society. It was emphasised that delegates had come together to support one another, which is why it was important to be open and honest with one another, and in Christ to accept and listen to one another. The meeting emphasised prayers and an apolitical stance, while nevertheless facing the issues of the day. This discussion session did not extend to church unity as per the synod decision or the mandate to the order commission (NGKA Akta, 1987).

In that the decision register of 1987 (Akta 1987), the chairperson reported on the March 1985 meeting between the DRC and the DRCA, convened by the DRC, during which church unity 
NGTT: Oopbron - http://ngtt.journals.ac.za

was discussed. In their response to the DRC's position that it believed the Church of Jesus Christ to be one, without different visible forms (implying it is invisible), the Rev Lebone's leadership stated that they too were still considering the matter of church unity, which implied that they concurred with the DRC's stance on the church's invisible unity. Thus, by not taking a stand on the matter, the DRCA missed an opportunity to state its position regarding church unity before the DRC. Instead, the DRCA leadership played into the hands of the DRC, frustrating visible and structural unity, by pleading that the leaders too had not taken any decision on such unity (Kgatla, 2011).

\section{The general synod of Umtata of 1987}

The general synod of Barkly West had already taken a firm stand on church unity, and the GSC was required to report to the general synod of Umtata on progress made in this regard. Based on point 2.6.1.2 of the agenda of the Umtata synod, the GSC referred the decision on church unity to the permanent law commission for the necessary attention and advice to the synod. The permanent law commission responded as follows: "The synod refers the decision of 1983 on church unity, that is, decision 1.2.1 on pages 344 to 347 of the Acta, together with all decisions that the synod will take during the meeting of 1987 , to the executive committee as the stand point of our church." ${ }^{4}$ The matter that was referred to the GSC was also referred to the law commission, and the law commission referred it to the executive committee - a timeconsuming process. Important to note is who among the members of the law commission referred the matter, and the ratio of white to black members of the commission: there were eight members of the commission in all, of whom five were white and three black. The report was finalised by two white members of the law commission, namely the Revv NW Basson and SO Skeen; in consequence, one should not take the report entirely at face value.

The synod then reiterated the position it took in Barkly West in 1983, and emphasised the importance of the decision taken there. In decisions 18.9.1 to 18.9.4 the synod emphasised the powers of the general synod in connection with decision 22 of the Bloemfontein synod. In decision 1.2.3.1 in connection with the unity of the members of the DRC, the DRCA stated that it did not support church division in the public life of the church. Therefore the synod reemphasised decisions 1.2.1.3.2.1 to 1.2.1.3.2.5 taken at Barkly West:

- Church unity is an obligation. The church is under obligation to proclaim this unity and to emphasise it wherever it goes.

- The diversity of spiritual gifts within the church (diversity within unity) was emphasised.

- The broader unity of the church was emphasised and it was stated that services should be open to all who wish to pray God in truth.

- The church exists through its members and it needs to model the truth and unity of Christ, which surpass human nationality and race.

- $\quad$ For the above to be fulfilled, the members of the DRC family choose the way of negotiation. If this way does not materialise, the church will be free to use the best way that will be suitable for the church (NGKA Akta, 1987).

4 Die Regskommissie wil graag die volgende aanbeveling aan die synode voorlê: Die sinode stuur die besluite wat hy in 1983 oor kerkeenheid geneem het, d.w.s. Besluit 1.2.1 op bld 344 tot 347 van die Akta, sowel as enige besluite wat hy tydens die vergadering van 1987 mag neem, na die Uitvoerende Komitte as die standpunt van ons Kerk. 
NGTT Deel 54, Nommers $3 \& 4$, September en Desember 2013

The general synod in Umtata took a firm stance to strengthen the decisions taken at Worcester, Umgababa and Barkly West, directing the synod to embrace church unity in a real sense of the word. The identity of the leaders at this time is important. The church was then in the hands of great thinkers, critical ministers of religion and theologians of the moment such as Dr SPE Buti (moderator), Rev MM Maphoto (assessor), Dr NJ Smith (actuary) and Dr MS Pitikoe (scribe). These were men of God who guided church unity talks to the point of the establishment of the Uniting Reformed Church in Southern Africa following the 1991 general synod of Pretoria (NGKA Akta, 1987).

\section{The general synod of Pretoria of 1991}

Prior to the general synod of Pretoria of 1991 there had been an extraordinary general synod sitting of the DRCA in October 1990 in Cape Town to discuss the implementation of the decisions of the DRCA over many years. In that synod a final decision was taken that the two churches, the DRCA and DRMC, would continue with the process of unification that would lead to unity between these two churches. The decision was final. The general synod of Pretoria in 1991 was given the task of implementing the decisions of the previous synods on church unity (NGKA Akta, 1991).

The synod of Pretoria took a different decision based on decision 1.2.1.3.2.5 of Barkly West, namely that the DRCA should choose the way of negotiation; if this proved unsuccessful, and the church was free to adopt the path it deemed best. In this synod the church approved the dissolution of church structures so as to be able to unite with the DRMC. The synod took the important decision to dissolve the general synod, regional synods and presbyteries. The legal existence of congregations continued. Based on the history of the DRCA, the church then existed as it had done between 1881 and 1963, in the form of congregations, before uniting on 7 May 1963 to constitute a single black general synod.

\section{THE DECISIONS OF THE DRCA IN RELATION TO THE FOURTH CONFESSION OF FAITH for the African Church}

According to the agendas and the Acta of the DRCA for the period that falls within the scope of this article, there is evidence of efforts by the DRCA to formulate the fourth confession of faith for the African church. The Belhar Confession of 1982 was supposed to be a solution to the protracted attempts of the DRCA to formulate the fourth African confession of faith. In the subsequent synods of the DRCA, namely Tshilidzini 1971, Umgababa 1979, Umtata 1987, Cape Town of 1990 (extraordinary synod) and finally Pretoria, Hatfield 1991, there had been discussions and debates concerning the formulation and adoption of the fourth confession of faith. These decisions are briefly highlighted below.

At the synod of Tshilidzini of 1971, decision 11.2 related to the fourth confession of faith. The synod accepted the recommendation of the Federal Council of Dutch Reformed Churches that there must be no changes in confessions of faith without consultation with all members. This decision suggests that changes in the confessions of the church had been considered. The federal council of the DRC family advised the synod that all members of the council should be consulted on this matter. In essence, the federal council was not in favour of changes to the confession, and were buying time by referring the matter to all members of the federal council of the DRC family. 
NGTT: Oopbron - http://ngtt.journals.ac.za

The fourth confession appears again on the agenda of the synod of Umgababa of 1979, where it was the subject of decision 14.4. The synod hesitated to act any further in this regard, considering that certain matters remained unresolved within the DRCA alone. However, the synod then instructed its commission on Bible study and confessions to begin drafting the fourth confession, with due emphasis on the African church's faith (NGKA Akta, 1979). In the agenda and the Acta of Barkly West of 1983 there is no indication that the commission had formulated the draft of the fourth confession of faith. We need to remember that the draft of the Belhar Confession was a year old and awaiting acceptance by the synod of the DRMC.

The synod of Umtata of 1987 made the Belhar Confession, which was accepted by the DRMC as their fourth confession, the subject of its decision 14.5. The DRCA referred the Belhar Confession to its commission for Bible study and confession for study and evaluation. Specific aspects to be considered were:

- the importance of the acceptance of the Belhar Confession by the DRCA

- how the acceptance of the Belhar Confession would contribute to church unity, and whether it would either promote or disrupt the unity process

The commission was required to make its findings available to the federal council of the DRC during the recess and make recommendations to the next synod.

The DRCA regional synod first discussed the Belhar Confession, the fourth confession adopted by the DRMC synod, in 1986. A vote was taken: 182 voted for, and 11 voted against, with one abstaining. During the meeting, some individual black ministers received threats via telephone from the DRC, warning them that they would lose their subsidies if they voted for the adoption of the Belhar Confession. Indeed, some of these threats were carried out later, when the DRC placed the stipend of a number of ministers on a sliding scale (glyskaal). The DRC was strongly opposed to the DRCA acceptance of the Belhar Confession, and was prepared to do everything in its power to frustrate the process. However, the theological insights and influence of the DRMC did not take root in the DRCA without resistance. The moderator (chairperson) of the synod, the Rev Lebone, who later led a splinter group that remains resistant to URCSA unity, objected from the chair. His stance was also evident in his moderator's report to the DRCA general synod held in Umtata in 1987 (Kgatla, 2011).

The synod of Pretoria, Hatfield discussed the report of Umtata 1987 on acceptance of the Belhar confession of faith. The synod of Pretoria, Hatfield of 1991 favoured implementation over talking, and did everything in its power to ensure the acceptance of the Belhar confession of faith. The Belhar Confession was accepted by the synod as the fourth confession of faith of the DRCA on the strength of a large majority vote. The acceptance of the Belhar Confession by this synod was a clear indication that the DRCA was now in a position to work towards reconciliation, justice, and ultimately church unity. The road travelled by the DRCA to reach this outcome was not an easy one, and involved overcoming the following hurdles:

- $\quad$ psychological factors (internalised superiority and internalised inferiority)

- leadership of the church (the right person in the right position at the right time)

- $\quad$ quality of theological training (inferior theological training led to a lack of critical thinking)

- $\quad$ missionaries (inferior white ministers trained to minister only to black congregations 
NGTT Deel 54, Nommers 3 \& 4, September en Desember 2013

feared that they would not match up to their brothers from the DRC and that they would never rise to leadership positions); as ambassadors sent by the DRC to serve the ideological interests of that church in the DRCA, they delayed the process

- $\quad$ economic factors, specifically, dependency on the DRCA (as a result of which the DRC placed the stipend of a number of ministers on a sliding scale)

- $\quad$ the federal council of the DRC

- discussions with the DRC when serious decisions were to be taken

These hurdles made a significant contribution in delaying the process of achieving church unity. It is sad to note that the same mentality prevails today within some of the member churches of the DRC family. It is therefore important to take note of such strategies when engaging in talks about the adoption of the Belhar Confession and church reunification.

\section{CONCLUSION}

This article has offered some historical background to the URCSA. In it I investigated various decisions of the general synods of the then DRCA from Tshilidzini in Venda in 1971 to Pretoria, Hatfield in 1991 regarding church unification. The research undertaken revealed significant efforts made by the DRCA to establish the United Reformed Church until it dissolved itself in preparation to uniting with the DRMC. It was also found that this church travelled a long way in an attempt to draft the fourth confession of faith up to the point where it received a gift from God in the form of the Belhar Confession, accepted at the synod of Pretoria of 1991. The acceptance of the Belhar Confession was a clear indication that the DRCA was committed to reconciliation, justice and church unity. This article takes cognizance of the struggle of the then DRCA to achieve reconciliation, justice and church unity among the DRC family members.

\section{BiBLIOGRAPHY}

Dreyer, A, 1936. Boustowwe vir geskiedenis van die Nederduitse Gereformeerde Kerk in Suid-Afrika. Deel III. Kaapstad: Jaarboekkommisie Raad van NG Kerke in SA.

Kgatla, T, 2011. On a bumpy road: historical survey of (unity) talks between the Dutch Reformed Church in Africa and the Dutch Reformed Church before 1994. Studia Historiae Ecclesiasticae Vol. XXXVIII, No. 2, December.

Luke, S and Van Houten, RL, 1997. Racism. Theological Forum Vol. XXV, No. 4, December.

Meiring, P, 2004. The Dutch Reformed Church Family in South Africa: Lessons learned on the way to Reconciliation (BestT, F, 2004. With a demonstration of the Spirit and of power). Geneva: WCC Publications.

NGKA Akta, 1971. Synodical Acts of the Nederduitse Gereformeerde Kerk in Afrika Third Synod. Bloemfontein: NG Sendingpers.

NGKA Akta, 1975. Synodical Acts of the Nederduitse Gereformeerde Kerk in Afrika Third Synod. Bloemfontein: NG Sendingpers.

NGKA Akta, 1979. Synodical Acts of the Nederduitse Gereformeerde Kerk in Afrika Third Synod. Bloemfontein: NG Sendingpers.

NGKA Akta, 1983. Synodical Acts of the Nederduitse Gereformeerde Kerk in Afrika Sixth Synod. Bloemfontein: NG Sendingpers.

NGKA Akta, 1987. Synodical Acts of the Nederduitse Gereformeerde Kerk in Afrika Seventh Synod. Bloemfontein: Sendingpers.

NGKA Akta, 1991. Synodical Acts of the Nederduitse Gereformeerde Kerk in Afrika Eighth Synod. Bloemfontein: Sendingpers.

Saayman, W, 2007. Being missionary, being human: an overview of Dutch Reformed mission history. 
NGTT: Oopbron - http://ngtt.journals.ac.za

Pietermaritzburg: Cluster Publications.

Thomas, D, 2002. Christ divided: Liberation, Ecumenism and Race in South Africa. Pretoria: Unisa Press Tingle, R, 1992. Revolution or Reconciliation? The struggle in the Church in South Africa. London: Christian Studies Centre. 